\title{
Applicability of Continuous Process Using Saturated and Superheated Steam for Boxed Heart Square Timber Drying ${ }^{1}$ (iํㄹ
}

\author{
Yonggun $\mathrm{PARK}^{2,3} \cdot$ Hyunwoo $\mathrm{CHUNG}^{2} \cdot$ Hyunbin $\mathrm{KIM}^{2} \cdot$ Hwanmyeong YEO ${ }^{2,3, \uparrow}$
}

\begin{abstract}
This study aims to evaluate applicability for the continuous drying process using saturated and superheated steam for large-square timber. During drying of the boxed heart square timber, changes in moisture content were examined through the slices of the surface, inner and core layers. The results showed that there was a large moisture content difference between the surface and inner layers during saturated steam drying and between the inner and core layers during superheated steam drying. However, despite the moisture content difference between the layers, no surface check occurred, and an internal check occurred only near the pith or juvenile parts of the wood. The maximum value of the drying stress of the dried larch boxed heart square timber, calculated from the elastic strain of the slice and the tangential elastic modulus of the larch, was 1.30 MPa. The tangential tensile strength of the larch was estimated at 5.21 $\mathrm{MPa}$ under temperature and moisture content conditions when drying stress was at a maximum. That is, in the continuous drying process, the saturated and superheated steam did not generate a check in the surface because the drying stress of the wood did not exceed the tangential tensile strength. In further studies, the superheated steam drying conditions will need to be relaxed to suppress the occurrence of internal checks. Such studies would make the continuous drying process using saturated and superheated steam available for the drying of large-square timber.
\end{abstract}

Keywords: drying stress, elastic strain, boxed heart timber, slice test, saturated and superheated steam drying, surface check

\section{INTRODUCTION}

As there is an increasing interest in the construction and use of hanok, and an emerging issue involving the repair and restoration of wooden cultural assets, there is an increasing demand for large-square timber. However, since large-square timber has a long moisture movement distance, and due to the low-grade structure of domestic timber, which are mostly small and/or medium size of wood and very likely to contain pith or juvenile wood, checks are likely to occur during drying. Since checks greatly affect the stability of buildings, it is very important to dry the wood so that checks do not occur. Kiln-drying method, which is the most commonly used commercially, is not appropriate for drying large-square timber quickly without the

${ }^{1}$ Date Received December 25, 2019, Date Accepted January 15, 2020

2 Department of Forest Sciences, College of Agriculture \& Life Sciences, Seoul National University, 1 Gwanak-ro, Gwanak-gu, Seoul 08826, Republic of Korea

${ }^{3}$ Research Institute of Agriculture \& Life Science, Seoul National University, 1 Gwanak-ro, Gwanak-gu, Seoul 08826, Republic of Korea

† Corresponding author: Hwanmyeong YEO (e-mail: hyeo@snu.ac.kr, ORCID: 0000-0002-1779-069X) 
occurrence of drying defects such as checks. Studies have therefore been conducted to reduce the defects that show up in drying large-square timber using various drying techniques. However, in case of natural drying, it takes too long to dry (Jung et al., 2003), and in the case of high temperature drying, a complete prevention of internal checks is difficult (Lee et al., 2013; 2016b; 2016c). In addition, high frequency drying or microwave drying has disadvantages, since they do not guarantee the safety of the user (Jung et al., 2002; 2004; Lee and Kim, 2009). In addition to drying techniques, studies have been conducted on methods of transforming the timber such as incising or center-boring treatments, but they are not desirable because of the cost associated with further processing (Lee et al., 2012; Lee et al., 2016a; 2016b; Pang et al., 2017). In order to improve on the existing techniques and/or come up with a new drying technique that can overcome these drawbacks, theoretical and experimental studies are being conducted to predict and control moisture transfer and changes in drying stress distribution in the wood (Kang et al., 2006; Park et al., 2014; 2017a; 2017b; Chang et al., 2017; Kim et al., 2017; Amer et al., 2019; Han et al., 2019a; 2019b).

In this study, we tried to evaluate the possibility of drying large-square timber without occurring checks using the drying method in which saturated steam and superheated steam were continuously applied. Saturated steam is in an equilibrium with no apparent change because the number of molecules evaporating equals the number of gas molecules entering a liquid or solid form (Fig. 1H). Since saturated steam has 100\% relative humidity (RH), the equilibrium moisture content (EMC) of wood undergoing saturated steam becomes the fiber saturation point (FSP), and shrinking occurs when the moisture content decreases below the FSP. Also, as shown in Fig. 2, the EMC and FSP of wood are known to be lower at high temperature than at room temperature (Kang et al., 2008). That is, when wood is dried in high-temperature saturated steam, the wood surface dries only up to the FSP of the moisture content that is lower than the FSP at room temperature, thus leading to no shrinkage. As the free water inside the wood moves to the surface, the differences in moisture content between the wood surface and the interior are expected to be reduced during the early drying. Therefore, in this study, the larch boxed heart square timber was dried using high-temperature saturated steam while keeping a small moisture content difference between the surface and inner layers, followed by rapid drying using superheated steam, which we called a continuous drying process using saturated and superheated steam. During the drying process, $3 \mathrm{~mm}$ thick slices were taken from the surface, inner and core layers of the larch

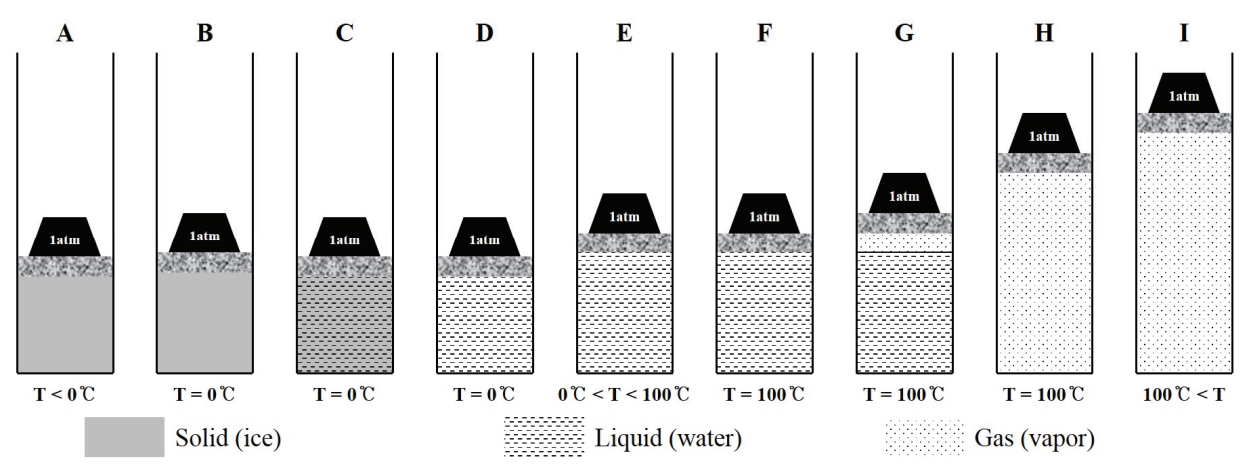

Fig. 1. Phase change of water with temperature change (Ro, 2008). 


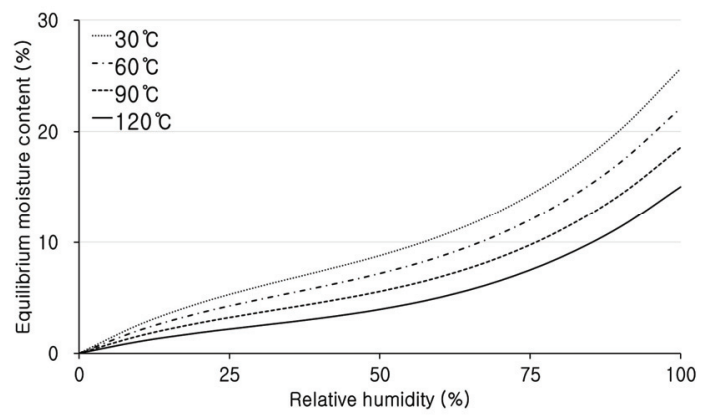

Fig. 2. Equilibrium moisture content of wood versus relative humidity at some temperatures according to the Hailwood-Horrobin equation.

boxed heart square timber in drying and were used to measure changes in the moisture content and the elastic strain and quantitatively evaluate drying stress of the square timber.

\section{MATERIALS and METHODS}

\subsection{Continuous drying process using saturated and superheated steam for larch boxed heart square timber}

Out of the larch with width and thickness of $10 \mathrm{~cm}$ respectively, the middle $2 \mathrm{~m}$ of the wood with a length of $2.7 \mathrm{~m}$ was used as specimens for drying, while 2 $\mathrm{cm}$ on both sides was used as specimens for measuring initial moisture content (Fig. 3).

Continuous drying process for the larch boxed heart square timber was first carried out with saturated steam with a temperature of $100^{\circ} \mathrm{C}$ and atmospheric pressure $(0.1 \mathrm{MPa})$ for 24 hours to remove free water in the wood. Then it was immediately followed by drying for 42 hours using superheated steam with a temperature of $220^{\circ} \mathrm{C}$ at the pressure of $0.5 \mathrm{MPa}$. Superheated steam drying was divided into 40 hours of a temperature rise period in which the superheated steam temperature was gradually increased and 2 hours of a concentrated heat treatment period in which the superheated steam

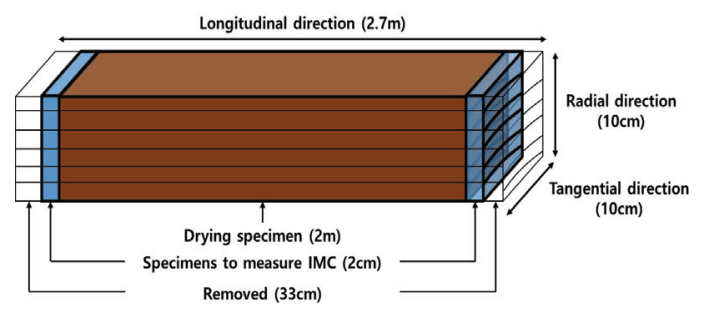

Fig. 3. Preparation of the specimen for the continuous drying process using saturated and superheated steam.

temperature was maintained at the highest point. After 66 hours of saturated and superheated steam drying, the dried larch boxed heart square timber was slowly cooled in the reactor for 12 hours to prevent checks. Thus, the whole continuous drying process using saturated and superheated steam took a total of 78 hours. Temperatures were measured on the wood center and the steam inside the reactor using a temperature sensor (K-type thermocouple, Fluke, WA, USA) attached to the wood dryer, and stored on a connected computer.

\subsection{Preparation of slices for drying stress analysis}

Since the continuous drying process is carried out in a closed reactor, it is impossible to continue to measure the changes in drying stress using a single wood specimen during the drying process. Therefore, after larch timbers with similar initial moisture content were dried under the same conditions until the set time, drying stress was measured. As for the measurement time point, four measurement time points (6 hours, 12 hours, 18 hours, 24 hours after the start of drying) were set in 6-hour units in the saturated steam drying section of 24 hours. In the 42 hour superheated steam drying section, there were five measurement points set, including 4 time points (10 hours, 34 hours, 44 hours, 54 hours, 64 hours after the start of drying) in 10-hour units for 40 hours and a time point at the end of superheated steam (66 hours after the start of drying). 


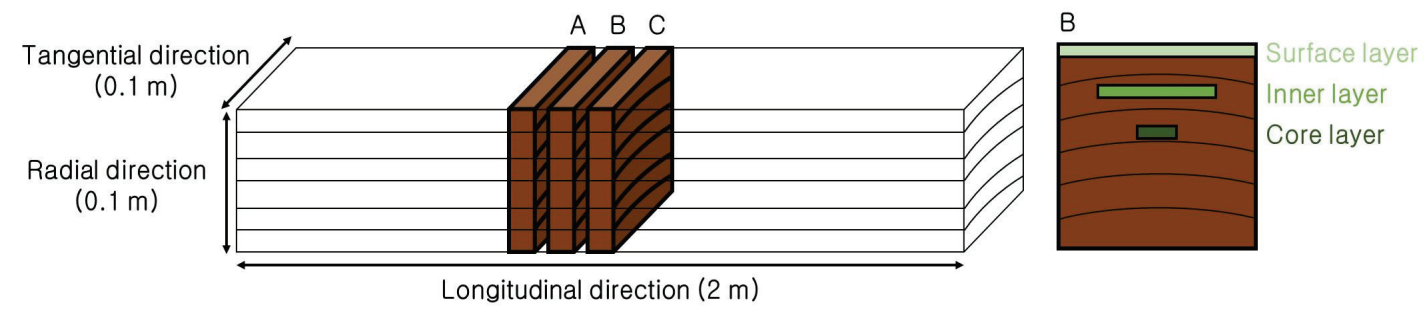

Fig. 4. Preparation of the specimens to measure average moisture content and to analyze drying stress in the square timber during the continuous drying process using saturated and superheated steam.

Thus along with the time point at the end of all drying processes (78 hours after the start of drying), there was a total of 10 measurement time points.

Fig. 4 shows the method of making slices for the analysis of the changes in drying stress inside the wood during the continuous drying process using saturated and superheated steam. After drying the $2 \mathrm{~m}$-long larch boxed heart square timber up to the set time, three specimens of $2 \mathrm{~cm}$ thickness were cut from the center of the wood that had no defects such as knots or checks. Specimens $\mathrm{A}$ and $\mathrm{C}$ were selected for the measurement of the average moisture content of the whole square timber, which was supposed to the average moisture content of the two specimens. Specimen B was used to measure the drying stress using slice method. Three slice specimens with 3-mm thickness were cut from specimen B shown in Fig. 4. Those were classified into the surface layer, inner layer, and core layer from the tangential surface furthest from the pith. Since unlike the lumbers, the square timber is expected to have the same water movement distance in the width direction and the thickness direction, the moisture content changes will be similar at the same distance from the center of the square timber. Thus, the length of each slice specimen was made different according to the layers.

That is, the slice specimen was $10 \mathrm{~cm}$ in length for the surface layer, $7 \mathrm{~cm}$ for the inner layer, and $4 \mathrm{~cm}$ for the core layer.

\subsection{Classification of dimensional changes in slices and calculation of drying stress}

In the analysis for the rheological behaviour of the wood in drying, the dimensional changes are classified into free shrinkage, actual shrinkage, elastic deformation, visco-elastic deformation, and viscous deformation as shown in Fig. 5 (Han, 2014), and to calculate these five deformations dimensions of the slice were measured in following five states: the initial length in green state $\left(L_{0}\right)$, the length of the wood shrunk due to decreased moisture content during drying (= widthwise length of specimen B immediately after cutting from the timber in drying, $\left.L_{1}\right)$, the length $\left(L_{2}\right)$ of the slice with a thickness of $3 \mathrm{~mm}$ momentarily changed immediately after cutting from the specimen $\mathrm{B}$, the length $\left(L_{3}\right)$ changed as the stress was relaxed over time with no change in moisture content, and the length $\left(L_{4}\right)$ of the slice

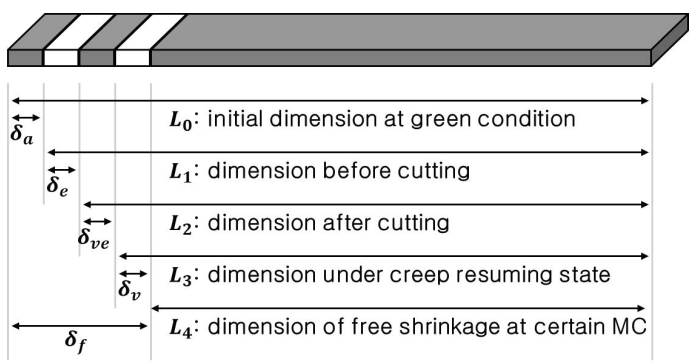

Fig. 5. Dimensional changes of slice during the drying process (Han, 2014). 
in which the maximum shrinkage without drying stress is applied. In this study, in order to calculate elastic strain for measuring the drying stress, only the widthwise length $\left(L_{1}\right)$ of the specimen B immediately after cutting from the square timber in drying and the widthwise length $\left(L_{2}\right)$ of the slice with a thickness of 3 $\mathrm{mm}$ momentarily changed immediately after cutting from the specimen B were measured. In addition, the elastic strain $\left(\varepsilon_{e}\right)$ was calculated according to Eq. (1) (Han et al., 2017).

$$
\varepsilon_{e}=\frac{\left(L_{1}-L_{2}\right)}{L_{1}}
$$

The stress generated in the wood during drying can be calculated according to Eq. (2), based on onedimensional linear elasticity (Ugoleve and Skuratov, 1992).

$$
\sigma=\varepsilon_{e} \cdot E
$$

Here, $\sigma$ denotes a drying stress (MPa) and $E$ denotes an elastic modulus (MPa). The values obtained through the tension test were corrected according to the temperature and moisture content of the slice during drying and used as the modulus of elasticity.

\subsection{Measurement of the tangential tensile strength and modulus of elasticity in larch wood}

In order to measure the tangential tensile strength and the modulus of elasticity, rectangular slices with width of $3 \mathrm{~cm}$ (radial direction), thickness of $2 \mathrm{~cm}$ (longitudinal direction), length of $15 \mathrm{~cm}$ (tangential direction) were manufactured according to $\ulcorner$ method of tension test for wood」 in Korean standard (KS F 2207). Then, as shown in Fig. 6, it was rounded off by a length of $7 \mathrm{~cm}$ and a width of $1 \mathrm{~cm}$ from the center

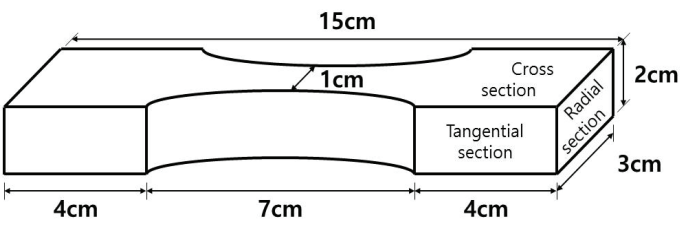

Fig. 6. Specimen for tension test in tangential direction.

in the longitudinal direction. The 20 specimens were humidified in a chamber set at a temperature of $20^{\circ} \mathrm{C}$ and a relative humidity of $65 \%$. Tension test was carried out using a universal testing machine (10-ton UTM, Zwick, Germany) at a load rate of $3 \mathrm{~mm} / \mathrm{min}$.

\section{RESULTS and DISCUSSION}

\subsection{Continuous drying process using saturated and superheated steam for the larch boxed heart square timber}

Fig. 7 shows the changes in steam inside the reactor, the temperature inside the lumber and the pressure inside the reactor during the 78 hours of the the continuous drying process using saturated and superheated steam. During 24 hours of saturated steam drying, the steam inside the reactor had a temperature of $100-110^{\circ} \mathrm{C}$ and a pressure of 0.08-0.09 $\mathrm{MPa}$. Considering that the saturation temperature of the steam at $0.08 \mathrm{MPa}$ is about $93^{\circ} \mathrm{C}$ and the saturation temperature of the steam at $0.09 \mathrm{MPa}$ is about $97^{\circ} \mathrm{C}$, the temperature inside the reactor was maintained slightly higher than the saturation temperature during the saturation steam drying. Right after the saturated steam drying was completed, the heater was restarted, again raising the temperature and pressure of the steam inside the reactor. The temperature of the superheated steam slowly rose to $220^{\circ} \mathrm{C}$ for 40 hours, which was maintained for 2 hours. At this time, the temperature inside the larch boxed heart square timber increased with increasing temperature of the steam and was maintained at about 


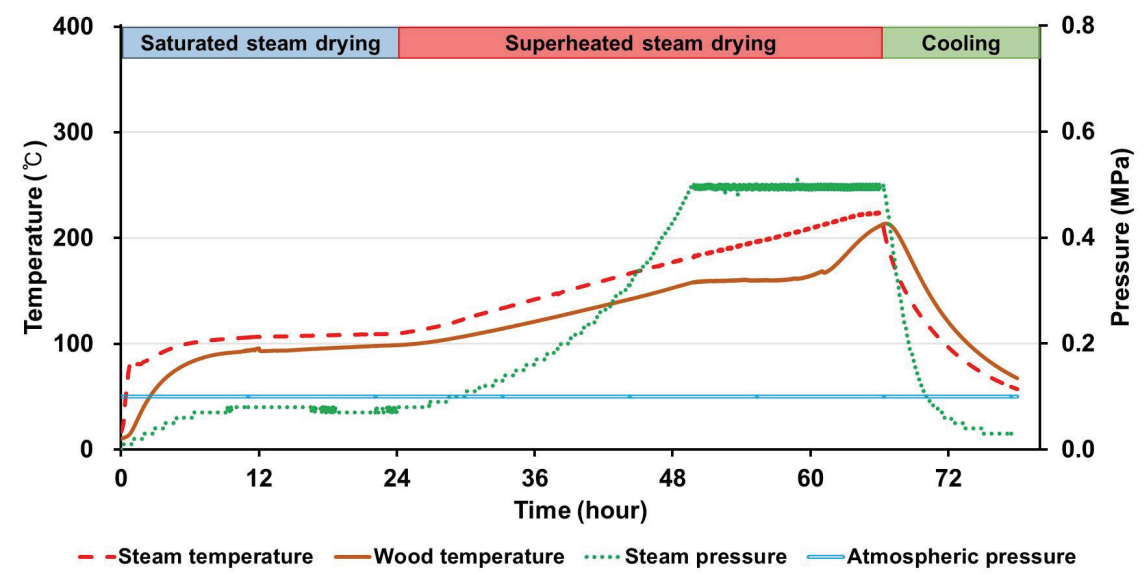

Fig. 7. Changes in steam temperature, wood temperature, and steam pressure during the continuous drying process using saturated and superheated steam.

$160^{\circ} \mathrm{C}$ from around 50 hours after the start of drying. Given that the saturation temperature of the steam at $0.5 \mathrm{MPa}$ is about $152^{\circ} \mathrm{C}$, it seems that the period where the temperature becomes constant is where the free water in the center of the larch boxed heart square timber is removed (Park et al., 2016). The internal temperature of the square timber begins to increase again at 60 hours, when the moisture content at the center of the square timber has fallen below the FSP. During the superheated steam drying, the maximum temperature at the center the square timber was about $215^{\circ} \mathrm{C}$. After the continuous drying process using saturated and superheated steam of 66 hours was completed, the dried square timber was gradually cooled in the reactor, so no checks occurred from sudden temperature change.

\subsection{Changes in moisture content of larch boxed heart square timber during the continuous drying process}

Fig. 8 shows the moisture content changes in the slices during the continuous drying process using saturated and superheated steam for the larch boxed heart square timber. The surface layer was dried at a

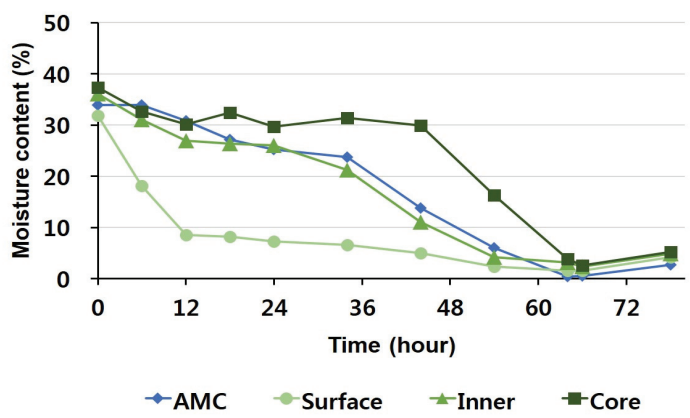

Fig. 8. Changes in moisture content of the slice during the continuous drying process using saturated and superheated steam.

very high rate at the beginning of the drying process and its moisture content dropped to $10 \%$ or less in 12 hours. On the other hand, the inner layer maintained a moisture content of about $25 \%$ during saturated steam drying, and then started to dry rapidly as the superheated steam drying started, dropping its moisture content down to $10 \%$ at 44 hours. The core layer maintained a moisture content of $30 \%$ even at 44 hours, which then rapidly dropped to about $3 \%$ at 64 hours. It is known that the differences in moisture content between the surface, inner and core layers are proportional to 

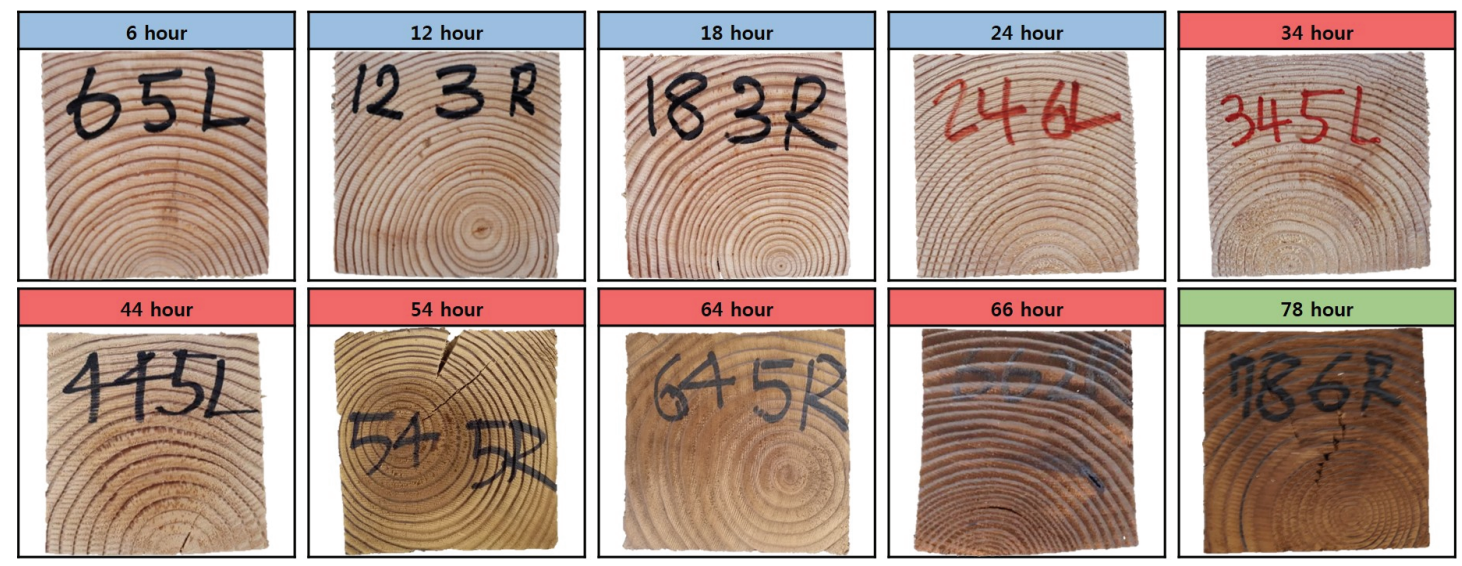

Fig. 9. Cross-sectional images at the center of the timber during the continuous drying process using saturated and superheated steam.

their drying stress. Thus, it can be estimated that the drying stress of the surface layer is largest between 12 and 36 hours, and the drying stress of the inner layer is largest between 44 and 54 hours.

\subsection{Evaluation of internal check occurrences during the continuous drying process}

Fig. 9 is a cross-sectional images at the center of the timber during the continuous drying process using saturated and superheated steam to determine whether internal checks occurred. During the saturated steam drying, despite the difference in moisture content between the surface and inner layers, no checks occurred on the surface. Because there was no difference in moisture content between the two layers, no checks occurred in the inner or core layers. During the superheated steam drying, some minor checks occurred on the surface and inner layers, but they were only near the pith or juvenile parts of the square timber. Most domestic large-square timber is very likely to contain pith or juvenile parts in the interior. Therefore, further studies are needed to study for the determination of the conditions under which no checks occur even in the pith or juvenile parts during the superheated steam drying.

\subsection{Changes in elastic deformation during the continuous drying process}

Fig. 10 shows the changes in elastic strain of the slices during the continuous drying using saturated and superheated steam for larch boxed heart square timber. Elastic strain indicates the instantaneous changes in length as soon as the stress is released immediately

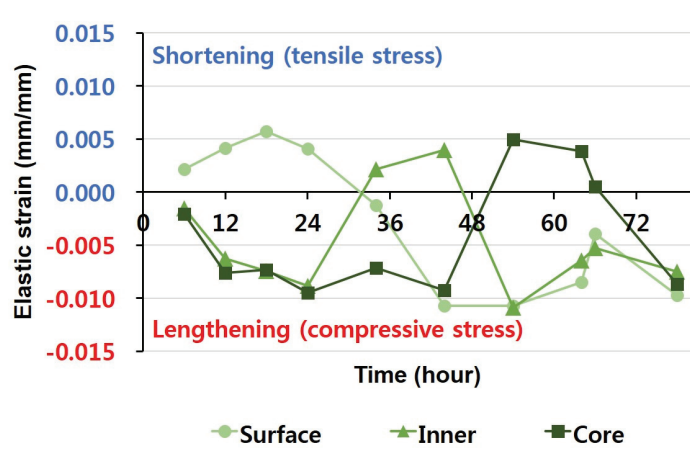

Fig. 10. Changes in elastic strain of slice during the continuous drying process using saturated and superheated steam. 
after the slices were cut from the specimen B, and are closely related to the drying stress that occurs in the wood. At the beginning of saturated steam drying (6 hours after the start of drying), the surface should be shrunk by relatively rapid drying. However, the shrinking of the surface layer was suppressed by the inner layer that still maintained the moisture content above FSP, and the surface layer was under tensile stress. At the same time, the inner and core layers were under compressive stress due to the shrinkage that occurred in the surface layer. As drying advanced, the tensile stress of the surface layer and the compressive stress of the inner and core layers decreased. At 34 hours after the start of drying, the surface layer no longer shrank and suppressed shrinkage of the inner layer. Thus, the inner layer was subjected to tensile stress, whereas the surface layer was subjected to compressive stress. For the same reason, after 44 hours from the start of drying, as the core layer also began to dry, the inner layer was under compressive stress again, and the core layer was placed under tensile stress. After the dried timbers were cooled in the reactor, all layers tended to shrink under compressive stress, which seems to be due to the high temperature heat treatment.

\subsection{Calculation of drying stress during the continuous drying process}

Checks occur along the radial direction on the surface or in the inner layer when the drying stress exceeds the tangential tensile strength and the drying stress of the slice is determined by the product of elastic deformation and modulus of elasticity. The elastic deformation in Fig. 10 shows that the tensile elastic strain has a maximum value $(0.0057 \mathrm{~mm} / \mathrm{mm})$ in the surface layer at 18 hours after the start of drying. The tangential tensile strength of the larch measured with the tension test was $6.51 \mathrm{MPa}$, the tensile modulus of elasticity was $304.72 \mathrm{MPa}$, and the moisture content was about $11.74 \%( \pm 0.20 \%)$. The strength and elastic modulus of wood are known to vary with moisture content and temperature (Kang et al., 2008; Zhan et al., 2009; Chan et al., 2011). Therefore, for larch specimens with moisture content of $11.74 \%$, the temperatures at which tensile strength and elastic modulus were measured should be corrected to those at 18 hours after the start of drying. Östman (1985) reported that the tensile strength and elastic modulus of spruce with moisture content of $10 \%$ decreased to $80 \%$ and $75 \%$, respectively, as the temperature increased from $25^{\circ} \mathrm{C}$ to $90^{\circ} \mathrm{C}$. In other words, at 18 hours after the start of drying, the tangential tensile strength of surface layer of the square timber in drying was estimated to be $5.21 \mathrm{MPa}, 228.54 \mathrm{MPa}$ for the tensile modulus of elasticity, and 1.30 MPa for the drying stress. Because the drying stress on the surface layer of the timber in drying did not exceed the tangential tensile strength of the timber, no checks occurred on the surface of the larch square timber.

\section{CONCLUSION}

In this study, to evaluate the applicability of the continuous drying process using saturated and superheated steam for large-square timber, larch boxed heart square timber was put under saturated steam of $100^{\circ} \mathrm{C}$ at $0.1 \mathrm{MPa}$ for 24 hours and superheated steam of $220^{\circ} \mathrm{C}$ at $0.5 \mathrm{MPa}$ for 42 hours, and under 12 hours of cooling. The slice method was applied to quantitatively evaluate the drying stress that occurred in the wood during the drying process, and slices with a thickness of $3 \mathrm{~mm}$ were prepared in the surface, inner and core layers. The moisture content in the surface layer dropped below $10 \%$ within 12 hours after the start of drying, and the moisture content of the inner layer tended to decrease gradually. The core layer maintained the moisture content above FSP up to 44 hours after the start of drying, followed by sharp decrease. Surface checks did not occur even though 
Applicability of Continuous Process Using Saturated and Superheated Steam for Boxed Heart Square Timber Drying

the moisture content difference of the surface layer and the inner layer were large during saturated steam drying, but some surface and internal checks occurred in the pith or juvenile parts during superheated steam drying. The elastic strain of the slices showed a maximum value $(0.0057 \mathrm{~mm} / \mathrm{mm})$ on the surface layer at 18 hours after the start of drying, and the drying stress at that time was estimated to be $1.30 \mathrm{MPa}$. In addition, the tangential tensile strength of the larch wood at the conditions of temperature and moisture content when the elastic strain of slices had a maximum value was measured to 5.21 $\mathrm{MPa}$. Therefore, because the drying stress of the surface layer did not exceed the tangential tensile strength of the larch wood, no surface checks occurred. However, further studies are needed to study for the determination of the conditions under which no checks occur even in the pith or juvenile parts during the superheated steam drying. It is expected then that the continuous drying process using saturated and superheated steam will allow for drying of larger size of the square timber.

\section{ACKNOWLEDGMENT}

This research was supported by Basic Science Research Program through the National Research Foundation of Korea (NRF) funded by the Ministry of Science, ICT and future Planning (NRF-2015R1D 1A1A01060308) and by the Ministry of Education (2018R1A6A3A01011937).

\section{REFERENCES}

Amer, M., Kabouchi, B., Alami, S.E., Azize, B., Rahouti, M., Famiri, A., Fidah, A. 2019. Water sorption/desorption kinetics and convective drying of Eucalyptus globulus wood. Journal of the Korean Wood Science and Technology 47(5): 557-566.

Chan, J.M., Walker, J.C., Raymond, C.A. 2011. Effects of moisture content and temperature on acoustic velocity and dynamic MOE of radiata pine sapwood boards. Wood Science and Technology 45(4): 609-626.

Chang, Y.S., Shin, H.K., Kim, S., Han, Y., Kim, M.J., Eom, C.D., Lee, Y.G., Shim, G.B. 2017. Evaluation of drying properties and yields of domestic Quercus species for enhancing utilization. Journal of the Korean Wood Science and Technology 45(5): 622-628.

Han, Y. 2014. Unsteady state analysis of moisture transfer and drying stress development in red pine wood. Ph.D. thesis, Seoul National University, Korea.

Han, Y., Yang, S.Y., Park, J.H., Chang, Y.S., Eom C.D., Yeo, H. 2017. Separation of drying strains and the calculation of drying stresses considering the viscoelasticity of red pine wood during drying. Drying Technology 35(15): 1858-1866.

Han, Y., Eom, C.D., Lee, S.M., Park, Y. 2019a. Moisture content change of Korean red pine logs during air drying: I . effective air drying days in major regions in Korea. Journal of the Korean Wood Science and Technology 47(6): 721-731.

Han, Y., Chang, Y.S., Eom, C.D., Lee, S.M. 2019 b. Moisture content change of Korean red pine logs during air drying: II . prediction of moisture content change of Korean red pine logs under different air drying conditions. Journal of the Korean Wood Science and Technology 47(6): 732-750.

Jung, H.S., Eom, C.D., So, B.J. 2004. Vacuum drying characteristics using different heating methods for douglas-fir timber. Journal of the Korean Wood Science and Technology 32(4): 18-26.

Jung, H.S., Kang, W., Lee, C.H. 2002. Comparison of drying characteristics of square timber by heated platen and radio-frequency/vacuum drying. Journal of the Korean Wood Science and Technology 30(2): 108-114.

Jung, H.S., Lee, C.H., Kang, W., Eom, C.D. 2003. 
Air-drying curve and moisture content distribution of softwood square timber. Journal of the Korean Wood Science and Technology 31(1): 27-31.

Kang, C.W., Kim, N.H., Kim, B.R., Kim, Y.S., Byeon, H.S., So, W.T., Yeo, H., Oh, S.W., Lee, W.H., Lee, H.W. 2008. Wood Physics and Mechanical Properties. Hyang Mun Sa, Seoul, Korea.

Kang, W., Lee, H.W., Chung, W.Y. 2006. Threedimensional distribution and variation of moisture content of boxed-heart square timber of Pinus densiflora during drying. Journal of the Korean Wood Science and Technology 34(1): 7-14.

Kim, H., Han, Y., Park, Y., Yang, S.Y., Chung, H., Eom, C.D., Lee, H.M., Yeo, H. 2017. Finite Difference Evaluation of Moisture Profile in Boxed-heart Large-cross-section Square Timber of Pinus densiflora during High Temperature Drying. Journal of the Korean Wood Science and Technology 45(6): 762-771.

Korean Standards Association. 2004. Method of Tension Test for Wood. KS F 2207.

Lee, C.J., Lee, N.H., Eom C.D., Shin, I.H., Park, M.J., Park, J.S. 2013. Effect of end-coating around pith of heavy timbers of red pine and Korean pine on high-temperature and low-humidity drying characteristics. Journal of the Korean Wood Science and Technology 41(3): 221-233.

Lee, C.J., Lee, N.H., Oh, S.W. 2016a. Effects of the knife and kerfing pretreatment on moisture content and surface check occurrence of douglas-fir heavy timber. Journal of the Korean Wood Science and Technology 44(3): 302-314.

Lee, C.J., Lee, N.H., Oh, S.W. 2016b. Effects of the knife-incising and longitudinal kerfing treatment on high-temperature drying characteristics of red pine square timber. Journal of the Korean Wood Science and Technology 44(5): 677-684.

Lee, C.J., Lee, N.H., Oh, S.W. 2016c. Studies of the high-temperature drying characteristics of douglas- fir, hemlock and radiata pine square timber. Journal of the Korean Wood Science and Technology 44(5): 726-735.

Lee, N.H., Zhao, X.F., Shin, I.H., Lee, C.J. 2012. Air circulating oven-drying chracteristics of hollowed round-post for Korean main conifer species - part 2: for Korean red pine hollowed round-post Journal of the Korean Wood Science and Technology 40(2): 61-70.

Lee, H.W, Kim, D.H. 2009. Study on the optimization of microwave log drying. Journal of the Korean Wood Science and Technology 37(4): 349-356.

Östman, B.A.L. 1985. Wood tensile strength at temperatures and moisture contents simulating fire conditions. Wood Science and Technology 19(2): 103-116.

Pang, S.J., Oh, J.K., Lee, S.J., Park, J.H., Jang, S.I., Lee, J.J. 2017. Surface checking reduction effect of preservative-treated Korean larch round-woods with various physical treatments. Journal of the Korean Wood Science and Technology 45(1): 107-115.

Park, Y., Eom, C.D., Han, Y., Park, J.H., Chang, Y.S., Yang, S.Y., Choi, J.W., Yeo, H. 2014. Combined treatment of green pitch pine wood by heat and superheated steam and the effects on physical properties of the products. Holzforschung 68(3): 327-335.

Park, Y., Park, J.H., Yang, S.Y., Chung, H., Kim, H., Han, Y., Chang, Y.S., Kim, K., Yeo, H. 2016. Evaluation of physico-mechanical properties and durability of Larix kaempferi wood heat-treated by superheated steam, Journal of the Korean Wood Science and Technology 44(5): 776-784.

Park, Y., Han, Y., Park, J.H., Chang, Y.S., Yang, S.Y., Chung, H., Yeo, H. 2017a. Evaluation of the energy efficiency of combined drying and heat treatment by superheated steam. Drying Technology 35(12): 1460-1467. 
Applicability of Continuous Process Using Saturated and Superheated Steam for Boxed Heart Square Timber Drying

Park, Y., Jang, S.K., Park, J.H., Yang, S.Y., Chung, H., Han, Y., Chang, Y.S., Choi, I.G., Yeo, H. $2017 b$. Changes of major chemical components in larch wood through combined treatment of drying and heat treatment using superheated steam. Journal of Wood Science 63(6): 635-643.

Ro, S.T. 2008. Engineering Thermodynamics. Munundang,
Seoul, Korea.

Ugolev, B.N., Skuratove, N.V. 1992. Stress-strain state of wood at kiln drying. Wood Science and Technology 26(3): 209-217.

Zhan, J.F., Gu, J.Y., Shi, S.Q. 2009. Rheological behavior of larch timber during conventional drying. Drying Technology 27(10): 1041-1050. 


\title{
APPENDIX
}

\author{
(Korean Version)
}

\section{대단면 수심정각재 건조를 위한 포화-과열증기 연속 건조 공정의 이용가능성 평가}

초록 : 본 연구에서는 대단면 목재의 건조를 위해 포화증기와 과열증기를 연속 적용하는 공정의 이용 가능성을 평가해보고자 하였다. 낙엽송 수심 정각재를 건조하는 동안 표면층, 내부층 및 중심층의 슬라이스 시험편을 통해 함수율 변화를 확인한 결과 포화증기 건조 중에는 표면층과 내부층 사이에서, 과열증기 건조 중에는 내부층과 중심층 사이에서 함수율 경사가 크게 발생하였다. 하지만 각 슬라이스 층간의 함수율 경사에도 불구하고, 표면 할렬은 발생하지 않았으며, 내부 할렬은 수나 미성숙재 부근에서만 발생하였다. 슬라이스의 탄성 변형률과 낙엽송의 접선 방향 탄성계수를 통해 건조 중인 낙엽송 정각재의 건조 응력의 최댓값은 $1.30 \mathrm{MPa}$ 이었고, 건조 응력이 최대인 시점 온도와 함수율 조건에서 낙엽송의 접선 방향 인장강도는 5.21 $\mathrm{MPa}$ 로 추산된다. 즉, 포화증기 및 과열증기를 연속 건조 공정에서 목재의 건조 응력이 접선 방향 인장강도를 초과하지 않았기 때문에 표면에서 할렬이 발생하지 않았다. 내부 할렬 발생 억제를 위한 과열증기 건조 조건 완화와 같은 추가 연구를 통해 포화-과열증기 연속 건조 공정이 대단면 목재 건조에 이용 가능할 것이라 기대된다.

\section{1. 서 론}

최근 한옥의 건축과 사용에 관한 관심이 증가하고, 목조 문화재의 수리 및 복원에 대한 문제가 사회적으로 대두되면서 대단면 목재(large-square timber)의 수요가 증가하고 있다. 하지만 대단면 목재는 수분 이동 거리가 길고, 소·중경목이 대부분인 국산 목재의 경급 구조상 대단면 목재에는 수나 미성숙재가 포함될 가능성이 매우 커 건조 중 할렬이 발생하기 쉽다. 할렬은 건축물의 안정성에 큰 영향을 미치기 때문에 할렬이 발생하지 않도록 건조하는 것은 매우 중요하다. 상업적으로 가장 보편적으로 이용되고 있는 열기 건조 방법으로는 대단면 목재를 할렬과 같은 건조 결함 발생 없이 신속하게 건조하기 어렵다. 따라서 다양한 건조 기술을 적용하여 대단면 목재의 건조 결함 발생을 줄이기 위한 연구가 수행되어왔다. 하지만, 천연 건조의 경우 건조에 걸리는 시간이 너무 길고(Jung et al., 2003), 고온 건조의 경우에는 내부 할렬 발생을 완전히 막을 수 없다는 단점이 있다(Lee et al., 2013; 2016b; 2016c). 또한, 고주파 건조나 마이크로파 건조의 경우 사용자의 안전을 완전히 보장할 수 없다는 단점이 있다(Jung et al., 2002; 2004; Lee and Kim, 2009). 건조 기술뿐만 아니라 자상(incising)처리나 중공(center-boring)처리 와 같이 재료에 변형을 가하는 방법에 대한 연구도 수행된 바 있으나, 추가 가공에 따른 비용 발생 등의 단점이 있다(Lee et al., 2012; Lee et al., 2016a; 2016b; Pang et al., 2017). 이와 같은 단점을 극복할 수 있는 새로운 건조 기술을 개발하고 기존 기술을 개선하기 위하여 목재 내부에 존재하는 수분의 이동과 건조 응력 분포의 변화를 예측하고 제어하기 위한 이론 및 실험 연구들이 수행되고 있다 (Kang et al., 2006; Park et al., 2014; 2017a; 2017b; Chang et al., 2017; Kim et al., 2017; Amer et al., 2019; Han et al., 2019a; 2019b).

본 연구에서는 포화증기와 과열증기를 연속하여 적용하는 건조 방법을 통해 대단면 목재를 할렬 발생 없이 건조할 수 있는지 에 대한 가능성을 평가해보고자 하였다. 포화증기는 증발하는 분자의 수와 액체나 고체 속으로 들어오는 기체 분자의 수가 같아져서 외관상으로는 변화가 없는 평형 상태의 기체를 말한다(Fig. $1 \mathrm{H})$. 포화증기는 상대습도가 $100 \%$ 이기 때문에 포화증기 내에서 목재의 평형함수율(equilibrium moisture content, EMC)은 섬유포화점(fiber saturation point, FSP)이 되고, 섬유포화점 이하로 수분이 감소할 때 수축 변형이 발생한다. 또한, Fig. 2와 같이 고온에서는 목재의 평형함수율 및 섬유포화점이 상온에서의 평형함수율과 섬유포화점보다 낮은 것으로 알려져 있다(Kang et al., 2008). 즉, 고온의 포화증기 내에서 목재가 건조될 때, 목재 표면은 상온에서의 섬유포화점보다 낮은 함수율의 섬유포화점까지만 건조되어 수축이 발생하지 않고 목재 내부의 자유수 는 목재 표면으로 이동하면서 목재 표면과 내부의 함수율 차이가 줄어든 채로 초기 건조가 이루어지는 효과를 기대하였다. 이에 따라 본 연구에서는 고온의 포화증기를 이용하여 낙엽송 정각재를 표면과 내부 사이의 함수율 차이가 작게 유지된 채로 건조한 다음, 바로 이어서 과열증기를 이용하여 빠르게 건조하는 포화-과열증기 연속 건조 공정(continuous drying process using saturated-superheated steam)의 가능성을 시험해보고자 하였다. 이때, 건조 중인 낙엽송 정각재의 표면과 내부 및 중심부에 서 $3 \mathrm{~mm}$ 두께의 슬라이스 시험편을 채취하여 함수율 변화 및 탄성 변형률(elastic strain)을 측정하고 이를 통해 건조 응력을 정량적으로 평가해보고자 하였다. 
Applicability of Continuous Process Using Saturated and Superheated Steam for Boxed Heart Square Timber Drying

\section{2. 재료 및 방법}

\section{1. 포화증기 및 과열증기를 이용한 정각재 연속 건조 공정}

본 연구에서 사용된 낙엽송은 폭과 두께가 $10 \mathrm{~cm}$ 이고, 길이가 $2.7 \mathrm{~m}$ 인 각재에서 가운데 $2 \mathrm{~m}$ 를 건조 시편으로 사용하였고, 건조 시편의 양쪽 $2 \mathrm{~cm}$ 는 초기 함수율 측정용 시편으로 사용하였다(Fig. 3).

포화증기 및 과열증기를 이용한 정각재 연속 건조는 목재 내 자유수 제거를 위해 24 시간 동안 대기압 $(0.1 \mathrm{MPa})$ 에서 $100^{\circ} \mathrm{C}$ 의 온도를 갖는 포화증기에서 건조를 수행한 다음, 바로 이어서 $0.5 \mathrm{MPa}, 220^{\circ} \mathrm{C}$ 의 온도를 갖는 과열증기를 이용하여 42 시간 동안 건조하였다. 과열증기 건조는 과열증기 온도를 서서히 상승시키는 온도 상승 구간 40 시간과 과열증기 온도가 최고점에서 일정하게 유지되는 집중 열처리 구간 2시간으로 구분하였다. 66시간의 포화-과열증기 연속 건조가 종료된 후, 건조된 낙엽송 각재는 반응기 내에서 12 시간 동안 서서히 냉각시켜 할렬 발생을 방지하고자 하였다. 결과적으로 포화-과열증기 연속 건조 공정은 총 78 시간이 소요되었다.

건조가 진행되는 목재 건조기에 부착되어 있는 온도 센서(K-type thermocouple, Fluke, WA, USA)를 이용하여 목재 중심부의 온도와 반응기 내부 증기의 온도를 측정하였고, 측정된 값은 연결되어 있는 컴퓨터에 저장되었다.

\section{2. 건조 응력 분석을 위한 슬라이스 시험편 제작}

포화-과열증기 연속 건조 공정은 밀폐된 반응기 내에서 건조가 이루어지기 때문에 건조가 진행되는 동안 하나의 각재를 이용하여 건조 응력 변화를 연속적으로 측정하는 것이 불가능하다. 따라서 초기 함수율이 유사한 낙엽송 각재를 설정된 시간까지 같은 조건으로 건조한 다음 건조 응력을 측정하였다. 측정 시점은 24 시간의 포화증기 건조 구간에서는 6 시간 단위로 4 번의 측정 시점(건조 시작 후 6시간, 12 시간, 18 시간, 24 시간의 시점)을 설정하였고, 42 시간의 과열증기 건조 구간에서는 과열증기 온도를 서서히 상승시키는 40 시간 동안 10 시간 단위로 4번의 측정 시점(건조 시작 후 34 시간, 44시간, 54시간, 64 시간의 시점)과 과열증기 건조가 끝나는 시점(건조 시작 후 66시간의 시점)을 포함하여 5 번의 측정 시점을 설정하였으며, 모든 공정이 종료된 시점(건조 시작 후 78 시간의 시점)까지 전체 공정 내에서 총 10 번의 측정 시점을 설정하였다.

Fig. 4는 포화-과열증기 연속 건조 공정 중 각재 내부의 건조 응력 변화 분석을 위한 슬라이스 시험편을 제작하는 방법을 나타낸 그림이다. 각각 설정된 시간까지 $2 \mathrm{~m}$ 길이의 낙엽송 정각재를 건조한 다음, 옹이나 할렬과 같은 결함이 없는 각재의 가운데에서 두께 $2 \mathrm{~cm}$ 인 시편을 3 개 떼어냈다. $\mathrm{A}$ 시편과 $\mathrm{C}$ 시편은 각재 전체의 평균 함수율 측정을 위한 시편으로 두 시편 함수율의 평균이 각재 전체의 평균 함수율과 같다고 가정하였다. $\mathrm{B}$ 시편은 슬라이스법을 이용한 건조 응력 측정을 위한 시편으로 수에서 가장 먼 쪽의 접선 단면 표면부터 표면층(surface layer), 내부층(inner layer), 중심층(core layer)으로 구분하여 $3 \mathrm{~mm}$ 두께의 슬라이스 시험편을 제작하였다. 정각재는 판재와는 다르게 폭 방향과 두께 방향의 수분 이동 거리가 같아서 각재 중심을 기준으로 같은 거리에서는 함수율 변화가 유사하게 나타날 것으로 판단되어 슬라이스 시험편의 길이를 층에 따라 다르게 제작하였다. 즉, 표면층의 슬라이스 시험편은 $10 \mathrm{~cm}$, 내부층의 슬라이스 시험편은 $7 \mathrm{~cm}$, 중심층의 슬라이스 시험편은 $4 \mathrm{~cm}$ 길이로 제작하였다.

\section{3. 슬라이스 시험편 변형량의 구분 및 건조 응력 산출}

슬라이스 법을 이용한 건조 중인 목재의 유변학적 거동분석에서는 슬라이스의 치수 변화를 Fig. 5 와 같이 자유 수축 변형, 실제 수축 변형, 탄성 변형, 점탄성 변형 및 점성 변형으로 구분하고(Han, 2014), 이 다섯 가지 변형을 구하기 위하여 다음의 다섯 가지 상태에서 슬라이스의 길이를 구한다. 슬라이스 시편은 생재 상태에서 각재의 폭 방향 길이 $\left(L_{0}\right)$, 실제 건조 중 수분 감소 때문에 수축한 각재의 폭 방향 길이(= 슬라이스 시편 제작을 위해 떼어낸 시편의 폭 방향 길이, $\left.L_{1}\right), 3 \mathrm{~mm}$ 두께의 슬라이스 시험편 제작 직후 순간적으로 변화된 슬라이스 시험편의 폭 방향 길이 $\left(L_{2}\right)$, 슬라이스 시험편의 함수율 변화가 없는 상태에서 시간이 지남에 따라 응력이 완화되면서 변형된 길이 $\left(L_{3}\right)$, 건조 응력 없이 목재가 수축할 수 있는 최대 수축량을 적용한 슬라이스 시험편의 폭 방향 길이 $\left(L_{4}\right)$ 로 구분할 수 있다. 본 연구에서는 건조 응력 측정을 위한 탄성 변형률 계산을 위하여 건조 후 각재의 폭 방향 길이 $\left(L_{1}\right)$ 와 $3 \mathrm{~mm}$ 두께의 슬라이스 시험편 제작 직후 순간적으로 변화된 슬라이스 시험편의 폭 방향 길이 $\left(L_{2}\right)$ 만을 측정하였으며, 탄성 변형률 $\left(\varepsilon_{e}\right)$ 은 식 (1)에 따라 계산하였다(Han et al., 2017).

$$
\varepsilon_{e}=\frac{\left(L_{1}-L_{2}\right)}{L_{1}}
$$


건조 중 목재에서 발생하는 응력은 1차원의 선형 탄성에 기초하여 식 (2)와 같이 산출할 수 있다(Ugoleve and Skuratov, 1992).

$$
\sigma=\varepsilon_{e} \cdot E
$$

여기에서, $\sigma$ 는 건조 응력 $(\mathrm{MPa})$ 을 $E$ 는 탄성계수 $(\mathrm{MPa})$ 를 의미한다. 탄성계수는 인장 시험을 통해 구한 값을 건조 중 슬라이스 시편의 온도와 함수율에 맞게 보정하여 사용하였다.

\section{4. 낙엽송재의 접선 방향 인장강도 및 인장 탄성계수 측정}

접선 방향 인장강도와 인장 탄성계수를 측정하기 위하여 한국산업규격의『목재의 인장 시험 방법 (KS F 2207)』에 따라 폭 $3 \mathrm{~cm}$ (방사방향), 두께 $2 \mathrm{~cm}$ (섬유방향), 길이 $15 \mathrm{~cm}$ (접선방향) 크기의 직육면체 시편을 제작한 다음, $\mathrm{Fig}$. 6과 같이 길이 방향으로 가운데에서 길이 $7 \mathrm{~cm}$, 폭 $1 \mathrm{~cm}$ 크기만큼 둥글게 깎아낸 시편을 20 개 제작하였다. 제작된 시편은 온도 $20^{\circ} \mathrm{C}$, 상대습도 $65 \%$ 로 설정된 항온항습기에서 조습시켰다. 인장 시험은 만능강도시험기(10-ton UTM, Zwick, Germany)를 이용하여 $3 \mathrm{~mm} / \mathrm{min}$ 의 하중 속도로 수행하였다.

\section{3. 결과 및 고찰}

3.1. 포화증기 및 과열증기를 이용한 정각재 연속 건조 공정

Fig. 7은 78시간 동안 진행된 포화-과열증기 연속 건조 공정 중 반응기 내부 증기와 정각재 내부의 온도 및 반응기 내부 증기의 압력 변화를 나타낸 그래프이다. 24시간의 포화증기 건조가 진행되는 동안 반응기 내부 증기는 $0.08 \sim 0.09 \mathrm{MPa}$ 의 압력에서 $100 \sim 110^{\circ} \mathrm{C}$ 의 온도 범위를 가졌다. $0.08 \mathrm{MPa}$ 에서 수증기의 포화온도가 약 $93^{\circ} \mathrm{C}$ 이고, $0.09 \mathrm{MPa}$ 에서 수증기의 포화온 도가 약 $97^{\circ} \mathrm{C}$ 인 것을 고려하면 포화증기 건조가 진행되는 동안 반응기 내부는 포화증기보다 약간 높은 온도를 유지했음을 알 수 있다. 포화증기 건조가 종료되고 바로 이어서 히터가 재가동되면서 반응기 내부 증기의 온도와 압력은 다시 상승했다. 40 시간 동안 과열증기의 온도는 $220^{\circ} \mathrm{C}$ 까지 서서히 상승하였으며, 2 시간 동안 유지되었다. 이때 낙엽송 정각재 내부의 온도는 과열증기의 온도 상승과 함께 증가하다가 약 50 시간의 시점부터 약 $160^{\circ} \mathrm{C}$ 의 온도를 유지하였다. $0.5 \mathrm{MPa}$ 에서 수증기의 포화온 도가 약 $152^{\circ} \mathrm{C}$ 임을 고려하면, 온도가 일정해지는 구간은 정각재 중심부의 자유수가 제거되는 구간으로 볼 수 있다(Park et $a l .$, 2016). 정각재 내부 온도는 60시간 시점에서 다시 증가하기 시작하며, 이때 정각재 중심이 섬유 포화점 이하의 함수율로 떨어진 것으로 추정된다. 과열증기 건조가 진행되는 동안 정각재 중심의 최고 온도는 약 $215^{\circ} \mathrm{C}$ 였다. 66 시간의 포화-과열증기 연속 건조 공정이 종료된 후, 건조된 낙엽송 각재는 반응기 내에서 서서히 냉각됨으로써 급격한 온도 변화에 따른 할렬이 발생하지 않았다.

\section{2. 낙엽송 정각재 건조 중 함수율 변화}

Fig. 8은 낙엽송 정각재 포화-과열증기 연속 건조 공정이 진행되는 동안 슬라이스 시험편의 함수율 변화를 나타낸 그래프이다. 표면층은 건조 공정이 시작됨과 동시에 매우 빠른 속도로 건조되면서 12 시간 만에 함수율이 $10 \%$ 이하가 되었다. 반면에 내층은 포화증기 건조 중에는 약 $25 \%$ 의 함수율을 유지하다가 과열증기 건조가 시작되면서 빠르게 건조되기 시작해 44 시간의 시점에서 $10 \%$ 의 함수율까지 건조되었다. 중심층은 44시간의 시점까지도 $30 \%$ 의 함수율을 유지했고, 이후 급격히 건조되면서 64 시간의 시점에서 약 $3 \%$ 의 함수율까지 건조되었다. 표면층과 내부층 및 중심층 사이의 함수율 차이와 건조 응력은 비례하는 것으로 알려져 있으므로 표면층의 건조 응력은 12 시간에서 36 시간 사이에 가장 크고, 내부층의 건조 응력은 44시간에서 54 시간 사이에 서 가장 크다고 추정할 수 있다.

\section{3. 낙엽송 정각재 건조 중 내부 할렬 발생 여부 평가}

Fig. 9는 낙엽송 정각재 건조가 진행되는 동안 내부 할렬 발생 여부를 확인하기 위해 시간대별 정각재의 길이 방향에서 가운데 부위를 절단한 횡단면 사진이다. 포화증기 건조가 진행되는 동안에는 표면층과 내부층에서 함수율의 차이가 났음에도 불구하고 표면에서의 할렬은 발생하지 않았으며, 내부층과 중심층에서는 함수율 차이가 없었기 때문에 내부 할렬도 발생하지 않았다. 과열증기 건조가 진행되는 동안에는 표면과 내부에서 작은 할렬이 일부 발생하였으나 모두 수와 미성숙재 부위에서 발생하였다. 대부분의 국산 대단면재는 내부에 수나 미성숙재를 포함할 가능성이 매우 크기 때문에 할렬이 발생하지 않는 과열증기 건조 조건에 대한 추가적인 연구가 필요할 것이라 생각된다. 


\section{4. 낙엽송 정각재 건조 중 탄성 변형률 변화}

Fig. 10은 낙엽송 정각재 건조 중 슬라이스 시험편의 탄성 변형률 변화를 나타낸 그래프이다. 탄성 변형은 슬라이스 시험편 제작 직후, 건조 응력이 해제됨과 동시에 순간적인 길이 변화를 의미하며, 목재 내에서 발생하는 건조 응력과 밀접한 관련이 있다. 포화증기 건조 초기(건조 시작 후 6시간 시점)에는 표면층이 빠르게 건조되면서 수축한다. 하지만 아직 섬유 포화점 이상의 함수율을 유지하는 내부층에 의해 수축이 억제되기 때문에 인장 응력을 받게 된다. 동시에 내부층과 중심층은 표층에서 발생한 수축의 영향으로 압축 응력 상태에 놓이게 된다. 건조가 진행되면서 표면층의 인장 응력과 내부층의 압축 응력의 크기는 감소하며, 건조 시작 후 34 시간의 시점에서 표면은 더는 수축하지 않고, 내부층의 수축을 억제하기 때문에 내부층은 인장 응력 상태에 놓이게 되고, 표면층은 반대로 압축 응력을 받게 된다. 같은 이유에서 건조 시작 후 44시간의 시점이 지나면 중심층도 건조되기 시작하면서 내부층이 다시 압축 응력을 받게 되고, 중심층이 인장 응력에 놓이게 된다. 건조된 각재가 반응기 내에서 냉각된 후에는 모든 슬라이스 층이 압축 응력을 받으면서 수축하는 경향을 보였는데 이는 고온의 열처리에 의한 영향인 것으로 보인다.

\section{5. 낙엽송 정각재 건조 중 건조 응력 산출}

건조 중인 목재의 건조 응력은 탄성 변형률과 탄성계수의 곱으로 결정되며, 건조 응력이 접선 방향 인장강도를 초과할 때 표면이나 내부에서 방사 방향을 따라 할렬이 발생하게 된다. Fig. 10 의 탄성 변형률 결과를 보면 인장 탄성 변형률은 건조 시작 후 18 시간 시점의 표면층에서 최댓값 $(0.0057 \mathrm{~mm} / \mathrm{mm})$ 을 갖는 것을 알 수 있다. 인장 시험을 통해 측정한 낙엽송의 접선 방향 인장강도는 $6.51 \mathrm{MPa}$ 이었고, 인장 탄성계수는 $304.72 \mathrm{MPa}$ 이었으며, 시험에 사용된 시험편의 함수율은 약 $11.74 \%$ $( \pm 0.20 \%)$ 였다. 목재의 강도와 탄성계수는 함수율과 온도에 따라 변하는 것으로 알려져 있다(Kang et al., 2008; Zhan et al., 2009; Chan et al., 2011). 따라서 $11.74 \%$ 의 함수율을 갖는 낙엽송 시편에 대해 측정 시 온도 조건의 인장강도와 인장 탄성계수를 건조 시작 후 18 시간 시점에서 낙엽송 각재의 온도 조건과 함수율 조건으로 보정해야 한다. Östman(1985)은 $10 \%$ 의 함수율을 갖는 spruce의 인장강도와 탄성계수는 $25^{\circ} \mathrm{C}$ 에서 $90^{\circ} \mathrm{C}$ 로 온도가 증가할 때, 각각 $80 \%$ 및 $75 \%$ 수준으로 감소한다고 보고한 바 있다. 즉, 건조 시작 후 18 시간 시점에서 낙엽송 각재 표면층의 접선 방향 인장강도는 $5.21 \mathrm{MPa}$ 로, 인장 탄성계수는 228.54 $\mathrm{MPa}$ 로 추정할 수 있으며, 이때 건조 응력은 $1.30 \mathrm{MPa}$ 로 추산된다. 즉, 포화증기 건조가 진행되는 동안 목재 표면에서의 건조 응력이 목재의 접선 방향 인장강도를 초과하지 않았기 때문에 낙엽송 소경각재의 표면에 할렬이 발생하지 않았다.

\section{4. 결 론}

본 연구에서는 대단면 목재의 건조를 위해 포화증기와 과열증기를 연속 적용하는 공정의 이용 가능성을 평가하기 위하여 낙엽송 소경각재를 $0.1 \mathrm{MPa}, 100^{\circ} \mathrm{C}$ 조건의 포화증기에서 24 시간, $0.5 \mathrm{MPa}, 220^{\circ} \mathrm{C}$ 조건에서 42 시간 및 냉각 12 시간의 포화-과열 증기 연속 건조 공정으로 건조하였다. 건조가 진행되는 동안 목재 내에서 발생하는 건조 응력을 정량적으로 평가하기 위하여 슬라이스 법을 적용하였으며, 표면층과 내부층 및 중심층에서 $3 \mathrm{~mm}$ 두께의 슬라이스 시험편을 제작하였다. 표면층의 슬라이스 시험편의 함수율은 건조가 시작된 후 12 시간 만에 $10 \%$ 이하로 떨어졌으며, 내부층은 서서히 감소하는 경향을 보였고, 중심층은 건조 시작 후 44 시간의 시점까지 $30 \%$ 이상의 함수율을 유지하다가 이후 급격히 감소하는 경향을 보였다. 포화증기 건조가 진행되는 동안 표면층과 내부층의 함수율 경사가 크게 형성되었음에도 표면 할렬은 발생하지 않았으나, 과열증기 건조가 진행되 는 동안에는 수나 미성숙재 부위에서 표면 할렬 및 내부 할렬이 발생하였다. 슬라이스 시험편의 탄성 변형률은 건조 시작 후 18 시간 시점의 표면에서 가장 최댓값 $(0.0057 \mathrm{~mm} / \mathrm{mm})$ 을 나타내었으며, 이때의 건조 응력은 $1.30 \mathrm{MPa}$ 로 추산된다. 건조 중인 목재의 온도와 함수율 조건에서 낙엽송의 접선 방향 인장강도는 $5.21 \mathrm{MPa}$ 이므로 목재 표면의 건조 응력이 목재의 접선 방향 인장강도를 초과하지 않았기 때문에 표면 할렬이 발생하지 않았다. 다만, 수와 미성숙재 부위의 내부 할렬 발생을 줄이기 위하여 과열증기 건조 조건을 완화하는 추가적인 연구가 필요할 것이며, 이를 통해 포화-과열증기 연속 건조를 이용하여 더 큰 크기의 대단면 목재 건조가 가능할 것이라 기대된다. 